Review Article

www.ijrap.net

\title{
A COMPARATIVE STUDY ON CHIKITSA-SIDDHANT OF RAKTA-PRADOSHAJA VIKAR IN AYURVEDA AND MODERN SCIENCE: A REVIEW
}

Ekka Deepak ${ }^{1 *}$, Dubey Swati ${ }^{2}$, Khichariya S.D. ${ }^{3}$, Dhruw D.S. ${ }^{3}$, Parhate S.M. ${ }^{4}$

${ }^{1}$ P.G. Scholar, Department of Kaya Chikitsha N.P.A. Govt Ayurvedic college Raipur, Chhattisgarh, India

${ }^{2}$ P.G. Scholar, Department of Rasa Shastra \& Baishajya Kalpana N.P.A. Govt Ayurvedic college Raipur, Chhattisgarh, India

${ }^{3}$ Assistant Professor Department of Kaya Chikitsha N.P.A. Govt. Ayurvedic college Raipur, Chhattisgarh, India

${ }^{4}$ Professor \& HOD of Rasa shastra \& Baishajya Kalpana N.P.A. Govt Ayurvedic college Raipur, Chhattisgarh, India

Received on: 20/07/17 Accepted on: 28/08/17

*Corresponding author
E-mail: drdeepak.ekka6@gmail.com

DOI: 10.7897/2277-4343.085264

\section{ABSTRACT}

Skin disease are numerous and a frequently occurring health problem affecting all age group from the neonates to the elderly causes harm in number of ways. It is divided in to three layers epidermis, dermis, hypodermis with distinct role in the overall function of the body. It is thinnest $0.05 \mathrm{~mm}$ in eyelid and thickest in palms and sole $1.5 \mathrm{~mm}$. Skin is a largest immunological organs and is affected by both external and internal factors as well as innate and adaptive immune response. Many skin diseases like urticaria, psoriasis, eczema, blistering, dermatitis in which both genetic and environmental factors are play important role. It is Tridoshaj vyadhi specially Rakta dhatu, Pita and Kaph is responsible for skin disease hence examination of the skin and its disorder are considered under Raktavaha srotas (Blood disorders). In modern science they classify their treatment in Demulcent, Emollients, Adsorbent, Counter-irritation's and volatile oil's which is also originated from our herbal plants. In Ayurveda the line of treatment of skin disease is mentioned in very clearly on Chr. Sutra. 24/18. In modern therapy has only a conservative treatment but in Ayurveda Sanshodhana chikitsha are also available like Raktamokshana (venesuction), Vamana (Emesis), Virechana(Purgatives) So result are much batter in Ayurveda. Aim of this study is to compare the line of treatment of Ayurveda and modern science.

Keywords: Raktamokshana, Vamana, Virechana, Demulcent, Counter-irritation.

\section{INTRODUCTION}

According to Charak sutrasthan 28/11 most of the skin disease are mentioned in Rakta-Pradosaj vikar ${ }^{1}$ (Blood disorder), Moola of Raktavaha srotas (Blood disorder) is Yakrit \& Pliha ${ }^{2}$ properties of Rakta dhatu \& Pitta is similar so Pitta-shamak chikitsa will be done, in Ayurveda Samshmana \& Sanshodhana chikitsha are clearly described but Raktamokshana (Venesuction) is best therapy for this srotas and chikitsa siddhant is mentioned in Chr. Su.24/18 ${ }^{3}$. The skin is one of the most important organs of the body, performing diverse functions. It regulates body temperature by variations in the blood supply and sweat formation and play an important part in the general metabolism by absorbing the ultra-violet rays and utilizing them in the formation of Vitamin- $\mathrm{D}^{4}$ so important for growth and nutrition and any injury to the skin is followed by local and general effect depending upon the damage. Unbroken skin acts as a barrier to protect the underlying structure and to prevent bacterial infection. The acid metabolism secreted by the sweat and sebaceous glands and the presence of thermo labile lysozyme on skin are capable of lysing bacteria. Dilatation or constriction of superficial blood vessels produce loss of gain of heat respectively under the control of nervous system. The skin is a often a mirror of human body and mind. In many systemic diseases the skin condition may help the diagnosis and reflect the severity of illness. On the other hand, in some skin disease the general health may be adversely affected ${ }^{5}$. Impulse responsible for the sensation of itching pass along the same nerve root fibers but the sensation experienced differs qualitatively as well as quantitatively from pain liberation of Histamine in the skin cause itching and may be responsible for the itching of allergic reaction. Histamine is correlated with Kapha dosha and when it is released in the skin, histamine stimulates the cell innervated by the vasodilator fibers, elicits a vasodilator and excites curtained sensory nerves which cause the painful sensation of burning and itching characteristic of an allergic reaction and itching is common symptoms of all skin disease. Histamine is a ubiquitous substance. It is found widely distributed in animal and plant tissue. Pharmacologically it is a potent agent and affects many structure of the body. Histamine is firstly described by Windaus and Vogt in 1907 and isolation of the compound from ergot by Barger and Dale in 1910. ${ }^{6}$ Many physical and psychological disorder find expression on the skin of human body. Thus, the skin is a very important organ where all the three Doshas have in their own spheres of activity. Skin disease are beautifully described in ancient Ayurvedic classics, In contest of skin disorder Charaka described about 18 type of kustha. ${ }^{7}$ In modern therapy of drug applied tropically to the skin or mucous membranes produce therapeutic effects localized to the site of application. They act primarily by virtue of their physical, mechanical, chemical, biological attributes and may be divided into Demulcents, Emollients, Adsorbents and protective, Astringents, Irritants and Counter-irritants, Caustic, Keratolytics $^{8}$. It is applied externally in dusting powder, lotion and ointment for the treatment of Chronic ulcer, dandruff and parasitic skin disease.

\section{Cause of Raktavaha srotas dusthi ${ }^{9}$}

"Vidahiannapananni snigdhaushana dravani cha!

Raktavahini dushsyati bhajatam chaatapanilo "!!

(Ch. vi. 5/14) 
Table 1

\begin{tabular}{|c|c|c|c|c|c|}
\hline Kushtha & Visarpa & Pidika & Raktapitta & Raktapradra & Gudapaka \\
\hline Medrapaka & Mukhapaka & Pleehavridhi & Gulma & Vidridhi & Nilika \\
\hline Kamla & Vyanga & Pillu & Tilkalka & Dadru & Charmadal \\
\hline Switra & Pama & Kotha & Raktamandala & & \\
\hline
\end{tabular}

\section{Chikitsha Siddhant ${ }^{1}$}

"Kuryachshoditrogeshu raktapitthari kriyam! Virekoupvasam cha stravanam shoditasya cha"!! (Ch. su. 24/18)

\section{Nidan Parivarjan ${ }^{11}$}

Nidan parivarjana(Avoid causes) is the most important things in all disease because of Acharya Lolimbraja said on his text book Vaidya jeewana, if patients follow a proper diet due to related disease medicine show very good result but when the patients not followed a proper diet chart then medicine cannot show significant result on that particular disease.

\section{Samshodhana Chikitsha ${ }^{12}$}

Abhyantara Snehana: Mahatikta Ghrita, Mahakhadir, Ghrita, Tiktashatphala Grita, Triphala Ghrit.

Vamana Karma: Kutaj, Madanphala, Madhuka, Patol, Nimb.

Virechana Karma: Swet nishotha, Dantimula, Triphala.

Niruha Basti: Daruharidra, Patol, Nimb, Madanphala, Amaltas kwath, Mustaka Kalaka,

Nasya Karma: Dantimula, Maricha, Tulsi, Pippali, Karanj phala, Vidang, Saindhava.

Dhoompana: Vairechanik dhoom.

\section{Raktamokshana (Venesuction)}

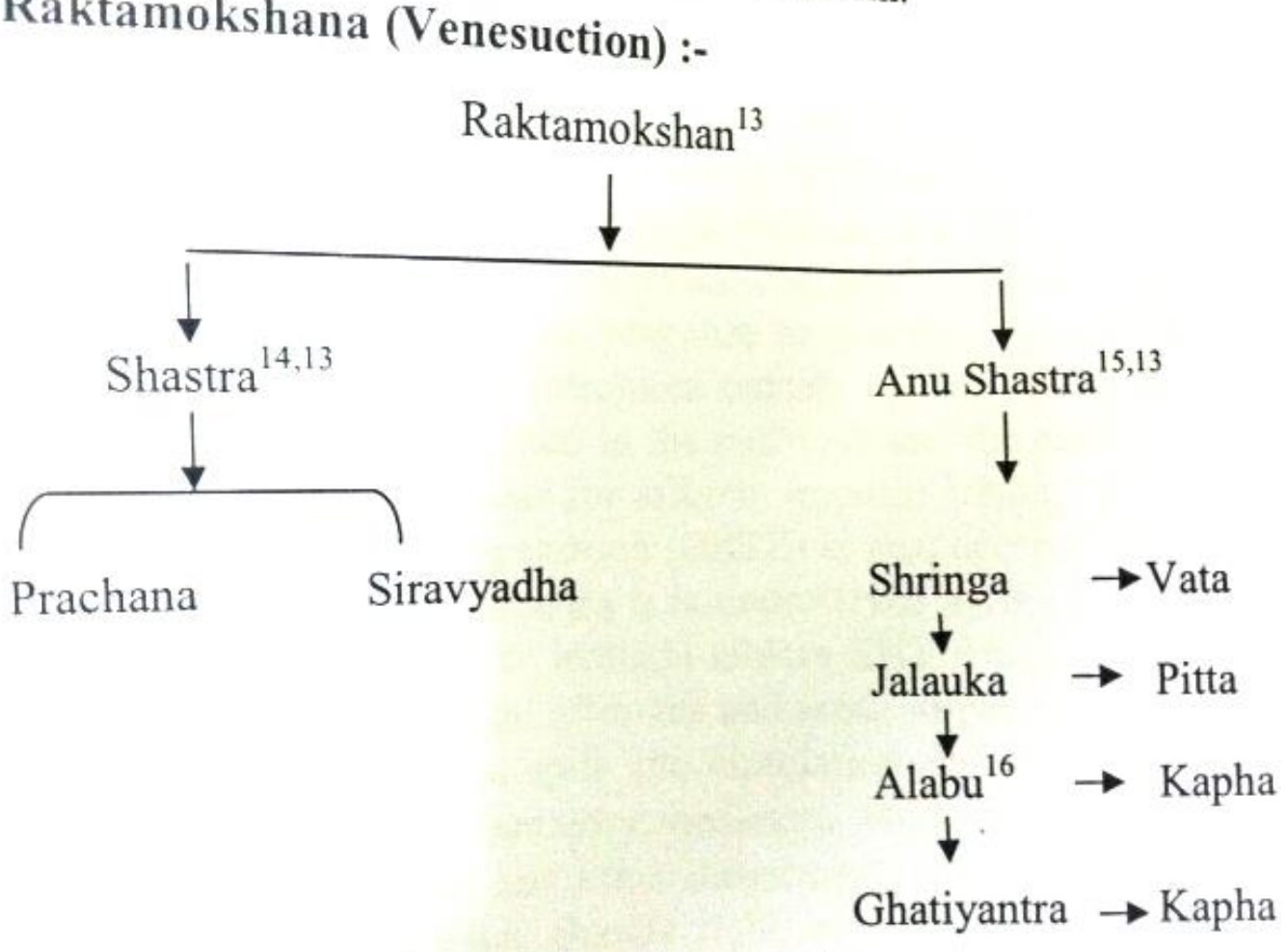

\section{Application of Raktamokshana According to Layer of Skin ${ }^{17}$}

- Superficial layer - Prachana

- Little deep layer - Jalouka(Leech)

- More dipper - Tumbi(Cupping)

- Deepest layer - Shringa

- Sarvanga shareera - Siravyadha (Venesuction)

Suitable Session for Raktamokshana ${ }^{13}$

Sharada Hritu because in this particular session Swabhavta Rakta Pradushti.

\section{Pharmacokinetics of Vamana ${ }^{18}$}

Vamana karma is the specific therapy for kaphaj vyadhi Vamana should always be preceded by suitable poorva karma in order to mobilize the doshas from the discrete parts of the body.
It is believed that imbalanced doshash spread from the kostha to shakhsa (Abdomen to limbs) \& thus to produce various types of disease depending upon dusya adhisthan pattern. To eradicate the imbalanced Doshas it is essential to mobilize the vitiated Doshas in the shakha \& to bring them back from shakha to kostha (Limbs to abdomen). so that they may be easily expelled out by vamanadi sanshodhan karma. vamaka dravyas get quickly absorbed in blood and cross the blood brain barriers and stimulates the vomiting center result into vomiting due to Usna, Tikshana, Sukshama, Vyavayi, Vikasi, Urdhavabhagha prabhava properties. The expelled material consists of undigested food, Kapha Dosha \& Pitta dosha. The vitiated Kapha dosha is expelled out through the mechanism of Vamana Karma and the disease process is stopped 


\section{Modern review of Vamana ${ }^{18}$}

The drug, which produces vomiting is called Emetics. The process of vomiting is called emesis. Vomiting results from the coordinated interaction of central \& peripheral neural, humeral, somatic Vol. IV No.1 Jan-Mar 2010 muscular and gastrointestinal myoelectrical muscular phenomena. Vomiting may be initiated by stimuli acting on a variety of anatomical structures within the central nervous system \& peripheral nervous system, The area postrema on the dorsal surface of the medulla at the caudal aspect of the fourth ventricle is believed to represent the chemoreceptor trigger zone (CRTZ) that is responsible to abroad range of neuro-chemical activators, other central nervous system sites mediate initiation of emetic response to selected stimuli. Finally, emesis may result from activation of peripheral structures outside of the central nervous system. Chemoreceptor trigger zone (CRTZ) located in the postrema and the nucleus tractus solitaries (NTS) are the most important relay areas for afferent impulse arising in the G.I.T., throat \& other viscera. The chemoreceptor trigger zone (CRTZ) is also accessible to blood borne drugs, mediators, hormones, toxins etc. because it is unprotected by the blood brain barrier. Cytotoxic drugs, radiations \& other G.I.T. irritants release SHT from entero chromaffin cells acts on sHTI receptors present on vagal afferents and sends impulses to NTS and CRTZ. Released in large quantity, SHT may also spill into circulation and reach CRTZ. It may as well be released from platelets by inflammatory mediators. However, SHT is not the only mediator of such signals, many peptides and other messengers are also involved. Various unpleasant sensory stimuli such as bad odor, ghastly sight, severe pain as well as fear, recall of an obnoxious event, anticipation of emetic stimulus cause nausea and vomiting through higher centers. The Vamana(Vomiting) process is carried out by two manners

\section{Pharmacokinetics of Virechana(Purgatives)Drugs ${ }^{18}$}

The mode of action of emetics as well as Purgatives is almost the same because they have more or less the same properties. The main action of Virechana (Purgative) dravyas is on Adhobhaga of the individual. The vitiated Pitta Dosha present in entire body is alleviated and expelled out through the mechanism of Virechana(Purgatives) and the disease process is arrested. The Virechana drug spreads throughout the body of cellular level due to its pharmacological properties.

- The Ushna property may help in increasing the quantum of Agni. it causes Vishyandana i.e. oozing of the Dosha in the Koshtha(abdomen)

- Tikshna properties of Virechana drugs produce chedana of the doshas, which are already softened due to oleation therapy or able to disintegrate the Sanghata of the Dosha. Thus, liquefied doshas are dragged towards the koshtha.

- Vyavayi properties of Virechana drugs is able to spread in the whole body prior to its digestion while Vikasi Guna able to scorch various dhatu and can compel the Dosha residing in it to come out.

Due to dominance of prithivi and Jala mahabhutas in the Virechana drugs and their potent Adhobhaga hara Prabhava, the vitiated doshas are made to pass through anal route (Guda) and are expelled out of the body.

\section{Drug acting on skin disease in modern}

The drug acting on the skin disease besides local anesthetics and antiseptic may be classified as follows ${ }^{5}$ :-

\section{Demulcents $^{8}$}

Demulcents are inert substances which sooth inflamed denuded mucosa or skin by prevention contact with air, irritant in the surrounding.

Glycyrrhizin- It is a sweet testing root used in cough lozenges to sooth the throat and as sweetening agent in mixture. It contains a glycosides glycyrrhizin which has steroid like salt retaining action when taken orally.

Methylcellulose- It is a synthetic cellulose derivative used as bulk purgative.

Glycerin- It is a clear, sweet viscous liquid. Undiluted glycerin dehydrating property. Applied to anal irritant suppository it induces evacuation.

\section{Emollients ${ }^{19}$}

Emollients drugs which soften or relax the skin upon which they applied. They are bland, oily or fatty substance and prevent cracking of the skin by supplying it with fat or moisture. Demulcent are substance of a viscid character which protect mucous membrane from irritation. E.g- Olive oil, Sesame oil, Almond oil, Glycerin, Honey, Liquorice.

\section{Adsorbents \& Protective ${ }^{20}$}

It is finely powered, inert and insoluble solids capable of binding to their surface noxious and irritant substance. They are also called protective because they effort physical protection to the skin or mucosa. e.g. Magnesium /zinc stearate, Talc, Calamine, Boric acid, Aloe era gel.

\section{Astringents ${ }^{22}$}

Astringents are substance the precipitate proteins, but do not penetrate cells thus affecting the superficial layer only. They toughen the surface making in mechanically stronger and decrease exudation -e.g. Tannic acid, Tannins, Alcohol.

\section{Counter-Irritants ${ }^{22}$}

Counter-irritant are used to stimulated nerve ending in intact skin to relief pain in viscera or muscle supplied by the same nerve root. All produce inflammation of the skin, the psychological effect is certainly important and other possibilities are:

The vaso-dilatation at the side of pain, produced either reflex or promote relief.

That the arrival of numerous pain impulse from the skin may alter the effect of impulse from other part supplied by the same nerve root. e.g. Volatile oils, Mustard seeds, Capsicum, Alcohols.

\section{Keratolytic ${ }^{23}$}

They are mid caustics and are used for softening and removing the Horney layer of skin. They are liable to damage normal skin and should there for be strictly confined to the lesion. If used too strong or for too long they may cause ulcer. They are used particularly in the chronic scaling condition EspeciallyPsoriasis, Salicylic acid $2 \%$ be the first choice.

\section{Caustic's ${ }^{23}$}

They are to destroy unwanted tissue, including wart's and corn's, condylomata, papilloma and on keratolytic lesions. Care is obviously necessary to avoid ulceration. It is believed that all micro-organism is killed during cauterization, but this is not always so. e.g.- Tricholoro acetic acid, Salicylic acid, Silver nitrate, Padophyllin. 


\section{Dusting powder ${ }^{23}$}

May be cool increasing the effective surface area of the skin and they reduce friction between skin surface by their lubricating action. Though usefully absorbent, they cause crushing if applied to exudative lesion. e.g.-Zinc starch, Talc dusting powder.

\section{Paste $^{23}$}

They are ointment containing insoluble powder. They are very adhesive and give good protection their powder content enables them to absorb a moderate amount of discharge.

\section{DISCUSSION}

According to modern science Vascular system is correlated with Raktavaha-srotas. Due to Samshodhana chikitsha like vamana, Virechana and Raktamokshana they are very good pitta shamak procedure with the help of Leech we done a jalouka(Leech) karma properties of Leech saliva is reported to have many therapeutic contents like hirudin, bdellins, Hyaluronidase, etc. among them, eglins and bdellins have anti-inflammatory and antifungal property which give relief in symptoms of skine disease $^{24}$ and when skin disease is due to kapha Upavasa karma is also helpful result is increase Vata \& Pitta dosa and Kapha shamak. Function of increased vata is kleda shoshaka and increased pitta also Aampachaka. According to A.H. sutra 1/25 mentioned Vasti-Virechana-Vamana is respectively best treatment for Vata-Pitta-Kapha and in skin disease specially Pitta and kapha dosha pradhana vyadhi, and so much drug are given in our text book for vamana-virechana kalpa ${ }^{25,26}$ but in modern science they use frequently immune-suppressive drug with several category like demulcents, emollients, adsorbents astringents, counter-irritant, keratolytic, caustic's and in irritants they used volatile oils they are also plant origin $\&$ in bulk amount used as a purgative which is similar to Virechana in Ayurveda. They frequently use Benzoic acid and Salicylic acid in skin disease which is also plant origin difference is only in modern science used only active constituents of each drug and in Ayurveda we are used whole plants. In both therapy used only a herbal drug. So above all this factor Chikitsa- Sidhhant are little similar to Ayurved and Modern science in Skin disease.

\section{CONCLUSION}

Ayurvedic herbs and herbal drugs play a key role in curing various skin ailments. Ayurvedic herbs have shown to prove effective in treating skin diseases. Ayurveda acharya Charak clearly mentioned in Charaka sutra 16:20 "Dosha kadachit kupyate jita langhanapachanai- Jita samshodhnairthe tu na tesham punurudhabhava."and also use of Immuno-modulator drug but in modern therapy has conservative treatment along with immune-suppressive medicine like Prednesolon and Hydrocortisone, because steroid have a synergistic effect as well as anti-inflammatory, anti-spasmodic and anti-histaminic property and that is very important function that's why in modern science frequently use a Steroid in Rheumatoid arthritis, Bronchial asthma and Skin disease. So result is batter in Ayurveda because advantage of Samshodhana chikitsha like Raktamokshana, vamana \& Virechana as compare to modern science.

\section{REFERENCES}

1. Pt. Kanshinath Pandey, Charak samhita Sutra Sthana Vividhasheetpitya Adhyay Choukhambha Bharti academy Reprint 2011 Varanasi, Page- 571.
2. Pt. Kanshinath Pandey, Charak samhita Vimana Sthana Srotvimaniya Adhyay Choukhambha Bharti academy Reprint 2011 Varanasi, Page- 711.

3. Pt. Kanshinath Pandey, Charak samhita Sutra Sthana Vidhishodita Adhayay Choukhambha Bharti academy Reprint 2011, Varanasi, Page- 445.

4. Birendra Nath Ghosh, Pharmacology Materia Medica and Therapeutics $7^{\text {th }}$ Edition: Hilton \& Co. 1944. kolkata. Page 666.

5. Sameer kumar Biswas, Pharmacology Materia Medica and Therapeutics $21^{\text {st }}$ Edition: Hilton \& Co. 1965, Kolkata Page 512.

6. John C. Krantz, Jr., C.Jelleff Carr. The Pharmacology Priciples of medical Practice $5^{\text {th }}$ Edition, The Williams \& Wilkins Company Baltomore 1961 Page- 1391.

7. Srivastava N, Saxena V. Role of Ayurveda in the management of skin disease Asian journal of modern and ayurvedic Medical science, Vol. 4, Number 1, January 01, 2015.

8. KD Tripathi Essential Medical Pharmacology $6^{\text {th }}$ Edition Jaypee Brothers Medical Publishers (P) Ltd. Reprint 2009, Delhi Page-845-848.

9. Pt. Kanshinath Pandey, Charak samhita Vimana Sthana Srotivimaniya Choukhambha Bharti academy Reprint 2011, Varanasi, Page- 713.

10. Pt. Kanshinath Pandey, Charak samhit Sutra SThana Vividhsheetpitiya Adhayay Choukhambha Bharti academy Reprint 2011 Varanasi,Page- 571.

11. Dr. Indra deva Tripathi by Lolimbaraja, Vaidyajivanam, Choukhambha Ayurved Pratishthan, Reprint 2011, Varanasi Page- 04.

12. Professor Ajay kumar Sharma, Kaya-chikitsha $2^{\text {nd }}$ Choukhambha Orientalia Reprint 2010, Delhi, Page - 827 .

13. Vaidya Haridas ShridharaAyurvediya Panchakarma Vigyana, $12^{\text {th }}$ Edition Shri Baidyanath Ayurveda Bhavana limited, 2006 Page - 501-502.

14. Kaviraja Ambikadutta Shastri Sushruta-Samhita Sutra Sthana Shonitavarniya Adhayay Choukhambha Sanskrit Samsthana Reprint 2010, Varanasi, Page-70.

15. Dr. Brahmanand Tripathi, Astanga-Hridayam Sutra Sthana Shastra vidhiadhayay Choukhambha Sanskrit Prathisthana Reprint 2007, Varanasi, Page - 287.

16. Dr. Brahmanand Tripathi, Astanga-Hridayam Shastra vidhiadhayay Choukhambha Sanskrit Prathisthana Reprint 2007, Varanasi,Page - 292-293.

17. Kaviraja Ambikadutta Shastri Sushruta-Samhita Sharir Sthana Siravyadha vidhi adhayay Choukhambha Sanskrit Samsthana Reprint 2010, Varanasi, Page-92.

18. Dr. Gopesh mangal, DR. Omprakash Sharma Pharmacokinetics of Vamana and virechana karma, Journal of Ayurveda, Vol. 4 No. 1 Jan-March 2010,

19. Birendra Nath Ghosh, Pharmacology Materia Medica and Therapeutics $7^{\text {th }}$ Edition Published by Calcutta: Hilton \& Co. 672 .

20. KD Tripathi Essential Medical Pharmacology $6^{\text {th }}$ Edition Jaypee Brothers Medical Publishers (P) Ltd. Reprint 2009, Delhi, Page-846.

21. KD Tripathi Essential Medical Pharmacology $6^{\text {th }}$ Edition Jaypee Brothers Medical Publishers (P) Ltd. Reprint 2009, Delhi, Page-847.

22. D.R. Laurence, Clinical Pharmacology, $4^{\text {th }}$ Edition, The English language book Society and Churchill Livingstone, 1973 Page -30.6 .

23. D.R. Laurence, Clinical Pharmacology, $4^{\text {th }}$ Edition, The English language book Society and Churchill Livingstone, 1973 Page - 30.3. 
24. Hiren N. Ravel and A.B. Thakar Role of Raktamokshana by Jalaukavcharana and siravedhana in the management of Vicharchika (Eczema) AYU-2012 Jan-March -33 (1) 68-72.

25. Dr. Brahmanand Tripathi, Astanga-Hridayam Sutra sthana Ayushyakamiya Adhayay Choukhambha Sanskrit Prathisthana Reprint 2007, Varanasi, Page - 20.

26. Dr. Anuja Hari Ghopal Skin and skin care in Ayurveda Juornal of dental and Medical sciences Vol. 14 Issue5 ver. 2 (May 2015) PP-57-60.

\section{Cite this article as:}

Ekka Deepak et al. A comparative study on Chikitsa-siddhant of Rakta-pradoshaja vikar in Ayurveda and modern science: A review. Int. J. Res. Ayurveda Pharm. 2017;8(5):150-154 http://dx.doi.org/10.7897/2277-4343.085264

\section{Source of support: Nil, Conflict of interest: None Declared}

Disclaimer: IJRAP is solely owned by Moksha Publishing House - A non-profit publishing house, dedicated to publish quality research, while every effort has been taken to verify the accuracy of the content published in our Journal. IJRAP cannot accept any responsib ility or liability for the site content and articles published. The views expressed in articles by our contributing authors are not necessarily those of IJRAP editor or editorial board members. 